\title{
Protocols for Enzymatic Fluorometric Assays to Quantify Phospholipid Classes
}

\author{
Shin-ya Morita *(D), Tokuji Tsuji and Tomohiro Terada \\ Department of Pharmacy, Shiga University of Medical Science Hospital, Otsu City, Shiga 520-2192, Japan \\ * Correspondence: smorita@belle.shiga-med.ac.jp; Tel.: +81-77-548-2681
}

Received: 18 December 2019; Accepted: 2 February 2020; Published: 4 February 2020

check for updates

\begin{abstract}
Phospholipids, consisting of a hydrophilic head group and two hydrophobic acyl chains, are essential for the structures of cell membranes, plasma lipoproteins, biliary mixed micelles, pulmonary surfactants, and extracellular vesicles. Beyond their structural roles, phospholipids have important roles in numerous biological processes. Thus, abnormalities in the metabolism and transport of phospholipids are involved in many diseases, including dyslipidemia, atherosclerosis, cholestasis, drug-induced liver injury, neurological diseases, autoimmune diseases, respiratory diseases, myopathies, and cancers. To further clarify the physiological, pathological, and molecular mechanisms and to identify disease biomarkers, we have recently developed enzymatic fluorometric assays for quantifying all major phospholipid classes, phosphatidylcholine, phosphatidylethanolamine, phosphatidylserine, phosphatidic acid, phosphatidylinositol, phosphatidylglycerol + cardiolipin, and sphingomyelin. These assays are specific, sensitive, simple, and high-throughput, and will be applicable to cells, intracellular organelles, tissues, fluids, lipoproteins, and extracellular vesicles. In this review, we present the detailed protocols for the enzymatic fluorometric measurements of phospholipid classes in cultured cells.
\end{abstract}

Keywords: enzymatic fluorometric measurement; phosphatidylcholine; phosphatidylethanolamine; phosphatidylserine; phosphatidic acid; phosphatidylinositol; phosphatidylglycerol; cardiolipin; sphingomyelin

\section{Introduction}

Phospholipids are amphiphilic molecules composed of a hydrophilic head group and two hydrophobic acyl chains, and are divided into glycerophospholipids (GPL) containing a glycerol backbone and sphingophospholipids containing a sphingosine backbone. Glycerophospholipids are further divided based on the head group structures into the following classes: phosphatidylcholine (PC), phosphatidylethanolamine (PE), phosphatidylserine (PS), phosphatidic acid (PA), phosphatidylinositol (PI), phosphatidylglycerol (PG), and cardiolipin (CL) (Figure 1). Sphingomyelin (SM), a major sphingophospholipid class, has a phosphocholine moiety in the head group. Lysophospholipids, lysophosphatidylcholine (LPC), lysophosphatidylethanolamine (LPE), lysophosphatidylserine (LPS), lysophosphatidic acid (LPA), lysophosphatidylinositol (LPI), and lysophosphatidylglycerol (LPG), contain only one acyl chain. Sphingosylphosphorylcholine (SPC) is a lyso-form of SM. Furthermore, these phospholipids vary widely in the acyl chain composition.

It has been previously reported that abnormalities in phospholipid metabolism and transport are closely associated with disorders, including dyslipidemia, atherosclerosis, cholestasis, drug-induced liver injury, neurological diseases, autoimmune diseases, respiratory diseases, cardiac and skeletal myopathies, and cancers [1-10]. Therefore, phospholipid classes have potential as biomarkers for these diseases, and it is highly desired to develop high-sensitive and high-throughput methods for analyzing phospholipid classes. 
PC

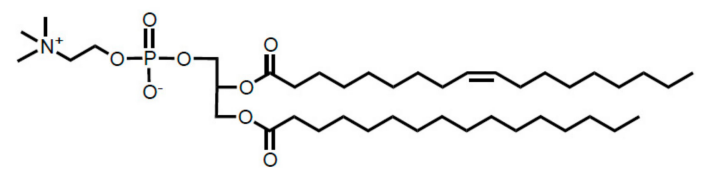

PE

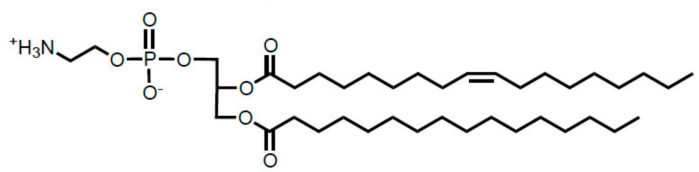

PS

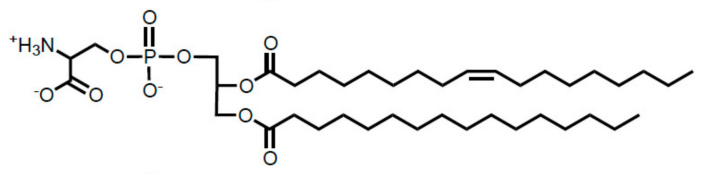

PA

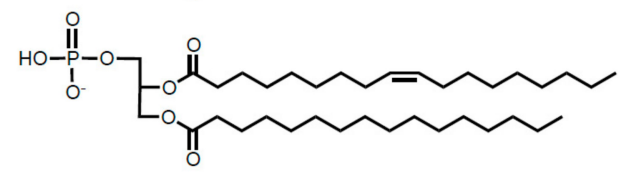

PI

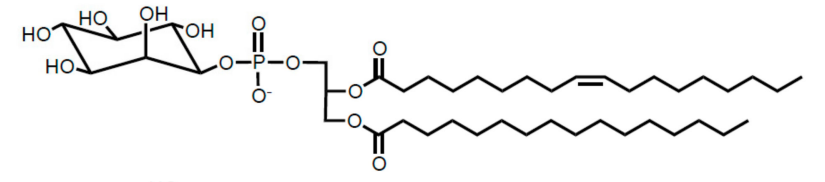

PG

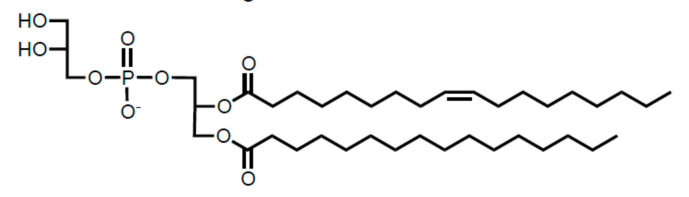

$\mathrm{CL}$

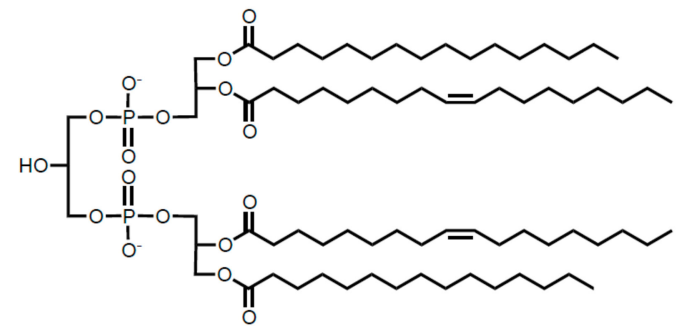

SM

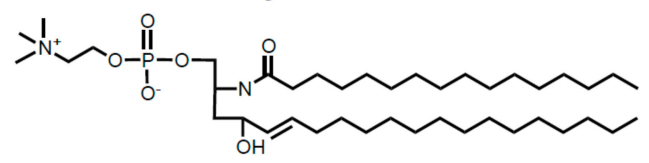

Figure 1. Structures of the phospholipid classes, phosphatidylcholine (PC), phosphatidylethanolamine (PE), phosphatidylserine (PS), phosphatidic acid (PA), phosphatidylinositol (PI), phosphatidylglycerol (PG), cardiolipin (CL), and sphingomyelin (SM). These phospholipid molecules contain various acyl chains.

The conventional assay for measuring phospholipid classes is thin-layer chromatography (TLC) followed by quantification of phosphate from the TLC spots [11]. However, this TLC-phosphorus assay is less sensitive, low throughput, time-consuming, and technically demanding. High-performance liquid chromatography (HPLC) equipped with an evaporative light-scattering detector or a corona charged aerosol detector has been used for the quantification of phospholipid classes [12-14]. Mass spectrometry has been applied to characterize phospholipid molecular species differing in acyl chain composition [15-19]. In mass spectrometric analyses, however, a large number of correction curves are needed for the quantification of each phospholipid molecular species because the ionization efficiencies differ among phospholipid species. In addition to these methods, we have recently completed the development of enzymatic fluorometric methods for quantifying all major phospholipid classes, which are specific, sensitive, simple, and high-throughput [18,20-24]. 


\section{Physiological Roles of Phospholipids}

\subsection{Cell Membranes}

Phospholipids, together with cholesterol, are necessary to assemble bilayer membranes in cells. In addition to the plasma membrane, the endoplasmic reticulum (ER), mitochondria, nuclear envelope, Golgi apparatus, lysosomes, endosomes, and peroxisomes are formed by bilayer membranes. In adipocytes, lipid droplets containing triglycerides are surrounded by phospholipid monolayers [25]. In mammalian cell membranes, the most abundant phospholipid is PC, constituting $40-50 \%$ of all phospholipids [26]. PE is the second most abundant mammalian phospholipid (20-50\%), whereas PS, PA, PI, and PG are quantitatively minor components of cell membranes [26]. SM, together with cholesterol, is highly enriched in lipid raft membrane microdomains [27]. CL is located in the mitochondria, primarily in the inner mitochondrial membranes [28]. In addition to the structural roles in membranes, phospholipids play crucial roles in numerous cellular processes, including membrane protein localization and regulation, membrane trafficking, autophagy, cell proliferation and differentiation, apoptosis, cell migration, and intracellular signaling. For example, during apoptosis, PS is externalized to the cell surface as an 'eat me' signal that is recognized by phagocytes [29]. Microtubule-associated protein 1 light chain 3, an autophagy marker, is conjugated with PE [30]. Through direct interaction, PA positively regulates the mammalian target of rapamycin, which controls cell cycle progression and cell growth [31]. In mitochondria, CL facilitates electron transfer and ATP production [32]. PI is further phosphorylated to $\mathrm{PI}(4) \mathrm{P}, \mathrm{PI}(5) \mathrm{P}, \mathrm{PI}(3) \mathrm{P}, \mathrm{PI}(4,5) \mathrm{P}_{2}, \mathrm{PI}(3,4) \mathrm{P}_{2}, \mathrm{PI}(3,5) \mathrm{P}_{2}$, and $\mathrm{PI}(3,4,5) \mathrm{P}_{3}$, which are implicated in diverse cellular functions $[7,33]$.

\subsection{Plasma Lipoproteins}

In the structures of plasma lipoproteins including high density lipoproteins (HDL), low density lipoproteins (LDL), very low density lipoproteins (VLDL), and chylomicrons, a hydrophobic core consisting of triglyceride and cholesteryl esters is enveloped by a surface monolayer consisting of phospholipids, cholesterol, and apolipoproteins [6]. In the formation of VLDL in hepatocytes and chylomicrons in enterocytes, the microsomal triglyceride transfer protein mediates the transfer of phospholipids from the endoplasmic reticulum membrane or another site to apolipoprotein B [6]. HDL is formed from cellular phospholipids and cholesterol through the interaction of apolipoprotein A-I with the ATP-binding cassette (ABC) transporter ABCA1 at the cell surface plasma membrane $[6,34,35]$. PC and SM are the main phospholipids in lipoprotein particles. The SM/PC ratio is $\sim 0.25$ in VLDL particles but increases to $\sim 0.5$ in LDL particles, because the degradation of SM is much slower than that of PC in plasma [6]. The PC/SM ratio in HDL is $~ 0.2$ [36]. The metabolism of lipoproteins is highly dependent on the composition of surface phospholipids through the regulation of binding of apolipoproteins or enzymes on the lipoprotein surfaces [6,37-39]. For example, SM at the lipid particle surface reduces the binding of apolipoprotein E to the particle [37]. Apolipoprotein E on the lipoprotein surface also binds to the LDL receptor, LDL receptor-related protein and heparan sulfate proteoglycans, which promotes the uptake of lipoprotein remnant particles by hepatocytes [6]. However, little is known about the roles of other phospholipid classes on the lipoprotein particle surfaces.

\subsection{Biliary Mixed Micelles}

In bile, bile salts, phospholipids, and cholesterol are the main lipid components, which form mixed micelles and vesicles. Bile salts damage cell membranes due to their detergent properties. The biliary phospholipids are necessary to protect hepatocytes from bile salt cytotoxicity $[8,40]$. The cytotoxicity of bile salts is attenuated by the formation of mixed micelles with phospholipids. PC is the predominant ( $>95 \%$ ) biliary phospholipid, whereas only small amounts of PE, PS, and SM are present in bile $[8,41]$. The phospholipid secretion from hepatocytes into bile is mediated by the transporter ABCB4 [41-44]. ABCB4 gene mutations cause a wide spectrum of liver diseases, 
including progressive familial intrahepatic cholestasis type 3, intrahepatic cholestasis of pregnancy, low phospholipid-associated cholelithiasis, primary biliary cirrhosis, and cholangiocarcinoma [8,41].

\subsection{Pulmonary Surfactants}

Pulmonary surfactants, extracellular complex of phospholipids, cholesterol and proteins, are secreted by type II alveolar epithelial cells, and reduce the incidence of alveoli to collapse during expiration [45]. The dysfunction of pulmonary surfactants disturbs alveolar gas exchange. In pulmonary surfactants, PC is the most abundant phospholipid class (70-80\%), and 1,2-dipalmitoyl PC is the most abundant molecular species [45,46]. The second most abundant phospholipid is PG, constituting up to $10 \%$, and PI, PE, and PS are also present in the surfactants $[45,46]$. PG and PI in pulmonary surfactants play key roles in regulating inflammatory processes within the lung [46]. In type II cells, the ABCA3 transporter protein is located at the limiting membrane of lamellar bodies, and plays an essential role in the biogenesis of lamellar bodies, likely by transporting phospholipids [3,47]. Phospholipids and proteins contained in the lamellar body are secreted into the alveoli and form films preventing alveolar collapse [3]. The majority of $A B C A 3$ mutations result in neonatal respiratory distress syndrome [3].

\subsection{Extracellular Vesicles}

Extracellular vesicles are secreted by almost all types of cells, and widely observed in body fluids, including blood, urine, milk, saliva, cerebrospinal fluid, and semen [48,49]. Extracellular vesicles consist of phospholipid bilayer membranes with transmembrane proteins and contain microRNAs, mRNAs, DNAs, and proteins [48,49]. Extracellular vesicles are categorized into three groups, exosomes (30-150 $\mathrm{nm}$ in diameter), microvesicles (100-1000 $\mathrm{nm})$ and apoptotic bodies $(1-5 \mu \mathrm{m})[48,49]$. Microvesicles and exosomes are generated from plasma membranes and endosomal compartments, respectively [48-50]. Multivesicular bodies filled with vesicles originate from endosomes and fuse with the plasma membranes to release exosomes into the extracellular space [48-50]. Recently, an increasing number of studies have demonstrated that extracellular vesicles play important roles in intracellular communication and many pathophysiologies [48-51]. In particular, extracellular vesicles from cancer cells target diverse types of normal cells to alter the microenvironment in order to support the cancer cell growth $[48,49,51]$. Thus, extracellular vesicles hold great promise as biomarkers. On the other hand, the roles of phospholipids in the bioactivities and fates of extracellular vesicles remain largely unknown, although several studies have analyzed the phospholipid composition of exosomes [51,52].

\section{Phospholipid Biomarkers}

As the level of serum phospholipids increases in patients with obstructive jaundice, the measurement of choline-containing phospholipids in serum is used as a clinical laboratory test to diagnose liver diseases $[53,54]$. Lipoprotein-X $(\mathrm{Lp}-\mathrm{X})$ is detected in the plasma of patients with extrahepatic and intrahepatic cholestasis caused by bile duct obstruction, hepatitis, primary sclerosing cholangitis, or primary biliary cholangitis $[9,55,56]$. Moreover, in patients with drug-induced cholestasis, plasma phospholipid and Lp-X levels markedly increase [1,57]. Lp-X is an abnormal lipoprotein rich in phospholipids and cholesterol, and is observed as vesicles of 50-70 $\mathrm{nm}$ in diameter [9]. The biliary phospholipid secretion mediated by Abcb4 is required for the appearance of Lp-X in bile duct-ligated mice, suggesting that Lp-X originates from biliary phospholipids moving into blood vessels under cholestatic conditions [9,58].

In addition to high levels of LDL-cholesterol and low levels of HDL-cholesterol, high plasma SM levels have been found to be an independent risk factor for coronary artery disease after adjusting for other risk factors [59]. Of note, LDL extracted from human atherosclerotic lesions exhibits a higher ratio of SM/PC than plasma LDL [60]. In arterial walls, sphingomyelinase (SMase) converts SM to ceramide in LDL, which leads to LDL aggregation and subsequent macrophage foam cell formation $[6,38,39,61]$. 


\section{Detection of $\mathrm{H}_{2} \mathrm{O}_{2}$ in Enzymatic Assays}

Our developed assays for measuring phospholipid classes (described in Section 6) fluorometrically detect enzymatically produced $\mathrm{H}_{2} \mathrm{O}_{2}$ in the final steps. This section describes several probes for detecting $\mathrm{H}_{2} \mathrm{O}_{2}$.

In the final steps of many enzymatic assays, enzymatically generated $\mathrm{H}_{2} \mathrm{O}_{2}$ is determined spectrophotometrically by reaction with chromogenic hydrogen donors catalyzed by peroxidase. As shown in Figure $2 \mathrm{a}$, the oxidative condensation of phenol with 4-amino antipyrine (4-AA) by $\mathrm{H}_{2} \mathrm{O}_{2}$ in the presence of peroxidase yields a red quinoneimine chromogen with an absorption maximum at $505 \mathrm{~nm}$, which has been widely used in clinical laboratory tests [53,62,63]. N-Ethyl-N-(2-hydroxy-3-sulfopropyl)-3,5-dimethoxyaniline (DAOS) and $\mathrm{N}$-ethyl- $\mathrm{N}$-(2-hydroxy-3-sulfopropyl)-3-methylaniline (TOOS) are also oxidatively coupled with 4-AA by $\mathrm{H}_{2} \mathrm{O}_{2}$, and these resulting chromogens have higher molar extinction coefficients and longer wavelengths of maximum absorption $(593 \mathrm{~nm}$ and $555 \mathrm{~nm}$, respectively) than the chromogen produced by the coupling of phenol and 4-AA [64].

(a)

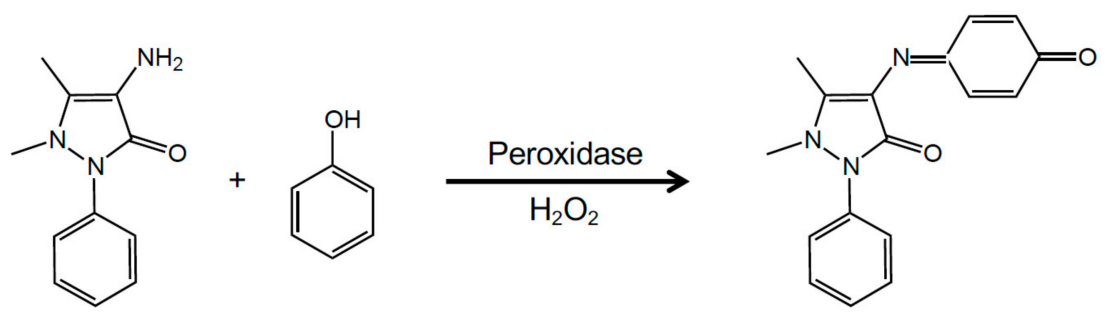

4-AA Phenol

Red quinoneimine chromogen $\left(\mathrm{Abs}_{\max } 505 \mathrm{~nm}\right)$

(b)

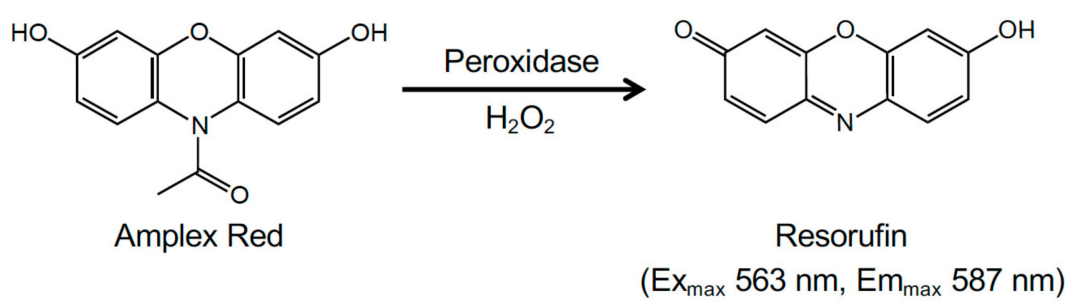

Figure 2. Detection of $\mathrm{H}_{2} \mathrm{O}_{2}$ in enzymatic assays. (a) The oxidative coupling of phenol and 4-AA by $\mathrm{H}_{2} \mathrm{O}_{2}$ in the presence of peroxidase produces a red quinoneimine chromogen (absorption maximum at $505 \mathrm{~nm}$ ). (b) The oxidation of Amplex Red by $\mathrm{H}_{2} \mathrm{O}_{2}$ in the presence of peroxidase produces highly fluorescent resorufin (excitation maximum at $563 \mathrm{~nm}$ and emission maximum at $587 \mathrm{~nm}$ ).

4-Hydroxyphenyl compounds, homovanillic acid, 4-hydroxyphenylacetic acid and 3-(4-hydroxyphenyl)propionic acid (HPPA), are fluorogenic substrates for peroxidase and have been employed for the $\mathrm{H}_{2} \mathrm{O}_{2}$ assay [65-67]. Using HPPA, $\mathrm{H}_{2} \mathrm{O}_{2}$ can be measured at as low as 100 pmol [67]. In the presence of $\mathrm{H}_{2} \mathrm{O}_{2}$, peroxidase catalyzes the dimerization of HPPA to form fluorescent bisphenol with excitation and emission maxima of $318 \mathrm{~nm}$ and $404 \mathrm{~nm}$, respectively [68].

10-Acetyl-3,7-dihydroxyphenoxazine (Amplex Red) is also applied for monitoring of $\mathrm{H}_{2} \mathrm{O}_{2}$ levels and in various enzymatic assays [69-73]. Peroxidase-catalyzed oxidation of Amplex Red, a nonfluorescent compound, by $\mathrm{H}_{2} \mathrm{O}_{2}$ generates highly fluorescent resorufin with an excitation maximum at $563 \mathrm{~nm}$ and emission maximum at $587 \mathrm{~nm}$ [69] (Figure 2b). The reaction stoichiometry of Amplex Red and $\mathrm{H}_{2} \mathrm{O}_{2}$ is 1:1. Amplex Red can detect as little as 2 pmol of $\mathrm{H}_{2} \mathrm{O}_{2}$ [71]. 


\section{Enzymatic Assays of Phospholipids}

Takayama et al. have developed the first enzymatic method to measure choline-containing phospholipids, PC, LPC, and SM, which involves three steps [53]. (1) PC, LPC, or SM is hydrolyzed by phospholipase D (PLD) from Streptomyces sp. to release choline. (2) Choline is oxidized by choline oxidase to betaine, which simultaneously generates $\mathrm{H}_{2} \mathrm{O}_{2}$. (3) In the presence of peroxidase, $\mathrm{H}_{2} \mathrm{O}_{2}$ couples phenol and 4-AA to produce a chromogen. This method does not distinguish among PC, LPC, and SM.

Enzymatic assays have been also reported for the specific measurement of SM by Blaton et al. [54]. In this assay, SM is selectively hydrolyzed by SMase from Bacillus cereus to liberate phosphocholine. Next, alkaline phosphatase catalyzes the cleavage of inorganic phosphate and the formation of choline. Choline is oxidized by choline oxidase, and the generated $\mathrm{H}_{2} \mathrm{O}_{2}$ is subsequently detected by phenol and 4-AA in the presence of peroxidase.

Hojjati and Jiang have reported an enzymatic method for the specific quantification of PC [74]. In the first step of this method, GPL-specific PLD (GPL-PLD) hydrolyzes PC, but not SM, to choline and PA. Choline is oxidized in a reaction catalyzed by choline oxidase to generate $\mathrm{H}_{2} \mathrm{O}_{2}$, which induces the coupling of DAOS and 4-AA in the presence of peroxidase as catalyst to yield a blue dye.

Ota et al. have reported the preliminary application of amine oxidase from Arthrobacter sp. to measure PE [75]. This PE assay consists of the hydrolysis of PE by PLD, oxidative deamination of ethanolamine by amine oxidase to generate $\mathrm{H}_{2} \mathrm{O}_{2}$, and oxidative coupling reaction between TOOS and 4-AA catalyzed by peroxidase.

\section{Enzymatic Fluorometric Assays for Quantifying Phospholipid Classes}

To enable comprehensive quantification of all major phospholipid classes in mammalian cells, we have developed methods for measuring PC, PE, PS, PA, PI, PG + CL, and SM using combinations of specific enzymes and Amplex Red [18,20-24]. This section describes the protocols for the enzymatic fluorometric assays for quantifying these phospholipid classes in cultured cells and intracellular organelles, which are slightly modified from those in the original reports mainly due to the availability of commercial enzymes (GPL-PLD for PC assay and glycerol-3-phosphate (G3P) oxidase for PA and PG + CL assays).

\subsection{Sample Preparation}

To determine the cellular phospholipid contents, cells are cultured in 10-cm dishes or 6-well plates. Cells were washed, scraped with cold phosphate-buffered saline, and sonicated to prepare cell homogenates. To determine the phospholipid contents in purified mitochondrial and microsomal fractions, cells are cultured in 10-cm dishes. Purified mitochondrial and microsomal fractions are isolated according to the previously described method [76]. The concentrations of protein in samples are measured by the bicinchoninic acid assay [77]. Phospholipids in cell homogenates or in purified mitochondrial and microsomal fractions are extracted by the modified method of Folch $[17,24,78,79]$. Lipid extraction from samples is recommended for the enzymatic measurements of phospholipid classes to remove water-soluble interfering compounds including choline, amines, amino acids, G3P, inositol, $\mathrm{NADH}$, and $\mathrm{H}_{2} \mathrm{O}_{2}$.

\subsection{Lipid Extraction}

\subsubsection{Materials}

- Chloroform ( $\geq 99.0 \%)(08402-55$, Nacalai Tesque, Kyoto, Japan).

- Methanol ( $\geq 99.8 \%)(21915-35$, Nacalai Tesque).

- Triton X-100 (<1 ppm $\mathrm{H}_{2} \mathrm{O}_{2}$ ) (10789704001, Roche Diagnostics, Mannheim, Germany).

\subsubsection{Procedure}

1. Pipette each sample $(1 \mathrm{~mL})$ into a glass tube.

2. Add chloroform/methanol (2:1) solution $(4 \mathrm{~mL})$ to each glass tube and vortex. 
3. Incubate overnight at $4{ }^{\circ} \mathrm{C}$.

4. Complete the phase split by centrifugation $\left(740 \times g, 20 \mathrm{~min}, 4^{\circ} \mathrm{C}\right)$.

5. Carefully remove the upper aqueous phase and the interfacial material using a glass Pasteur pipette.

6. Add $\mathrm{H}_{2} \mathrm{O}(1 \mathrm{~mL})$ to the recovered lower organic phase and vortex.

7. Complete the phase split by centrifugation and remove the aqueous phase again.

8. Evaporate the organic solvent from the lower phase.

9. Dissolve the evaporated sample with $1 \%$ Triton $\mathrm{X}-100$ solution $(200 \mu \mathrm{L})$.

\subsection{Protocol for Enzymatic Fluorometric Measurement of PC}

\subsubsection{Strategy}

There are three reaction steps for the enzymatic fluorometric measurement of PC [18] (Figure 3a).

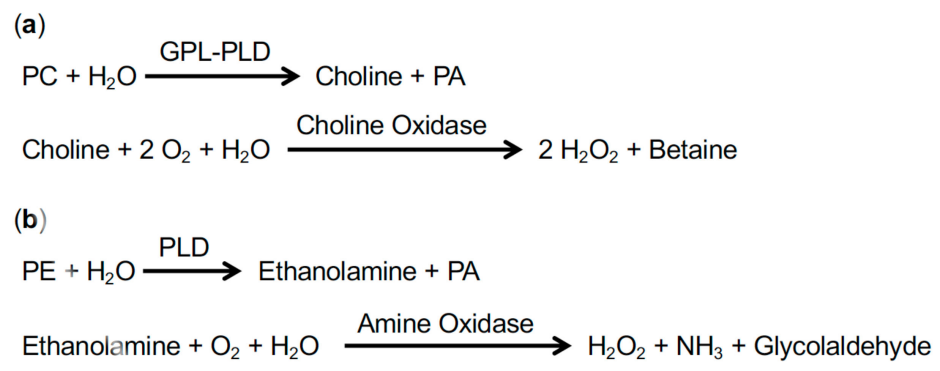

(c) PS $+\mathrm{H}_{2} \mathrm{O} \stackrel{\text { PLD }}{\longrightarrow}$ Serine + PA
Serine $+\mathrm{O}_{2}+\mathrm{H}_{2} \mathrm{O} \stackrel{\text { L-Amino Acid Oxidase }}{\longrightarrow} \mathrm{H}_{2} \mathrm{O}_{2}+\mathrm{NH}_{3}+$ 2-Oxo-3-hydroxypropionic Acid

(d) $\mathrm{PA}+2 \mathrm{H}_{2} \mathrm{O} \stackrel{\text { Lipase }}{\longrightarrow} \mathrm{G} 3 \mathrm{P}+2$ Fatty Acid
$\mathrm{G} 3 \mathrm{P}+\mathrm{O}_{2} \stackrel{\text { G3P Oxidase }}{\longrightarrow} \mathrm{H}_{2} \mathrm{O}_{2}+$ Dihydroxyacetone Phosphate

(e) $\mathrm{PI}+\mathrm{H}_{2} \mathrm{O} \stackrel{\mathrm{PLD}}{\longrightarrow}$ Inositol $+\mathrm{PA}$ myo-Inositol $+\mathrm{NAD}^{+} \stackrel{\text { myo-Inositol Dehydrogenase }}{\longrightarrow}$ scyllo-Inosose $+\mathrm{NADH}+\mathrm{H}^{+}$
$\mathrm{NADH}+\mathrm{H}^{+}+\mathrm{O}_{2} \stackrel{\mathrm{NADH} \text { Oxidase }}{\longrightarrow} \mathrm{H}_{2} \mathrm{O}_{2}+\mathrm{NAD}^{+}$

(f) $\mathrm{CL}+\mathrm{H}_{2} \mathrm{O} \stackrel{\mathrm{PLD}}{\longrightarrow} \mathrm{PG}+\mathrm{PA}$
$\mathrm{PG}+\mathrm{H}_{2} \mathrm{O} \stackrel{\mathrm{PLD}}{\longrightarrow}$ Glycerol $+\mathrm{PA}$
Glycerol $+\mathrm{ATP} \stackrel{\text { Glycerol Kinase }}{\longrightarrow} \mathrm{G} 3 \mathrm{P}+\mathrm{ADP}$
$\mathrm{G} 3 \mathrm{P}+\mathrm{O}_{2} \stackrel{\text { G3P Oxidase }}{\longrightarrow} \mathrm{H}_{2} \mathrm{O}_{2}+$ Dihydroxyacetone Phosphate

(g) $\mathrm{SM}+\mathrm{H}_{2} \mathrm{O} \stackrel{\text { SMase }}{\longrightarrow}$ Phosphocholine + Ceramide
Phosphocholine $+\mathrm{H}_{2} \mathrm{O} \stackrel{\text { Alkaline Phosphatase }}{\longrightarrow}$ Choline + Phosphate
Choline $+2 \mathrm{O}_{2}+\mathrm{H}_{2} \mathrm{O} \stackrel{\text { Choline Oxidase }}{\longrightarrow} 2 \mathrm{H}_{2} \mathrm{O}_{2}+$ Betaine

Figure 3. Strategies for enzymatic fluorometric measurements of PC (a), PE (b), PS (c), PA (d), PI (e), $\mathrm{PG}+\mathrm{CL}(\mathbf{f})$, and SM (g). In the final steps, $\mathrm{H}_{2} \mathrm{O}_{2}$ is detected using Amplex Red and peroxidase. 
1. PC is hydrolyzed by GPL-PLD to choline and PA.

2. Choline is oxidized by choline oxidase, generating two $\mathrm{H}_{2} \mathrm{O}_{2}$ molecules and betaine.

3. In the presence of peroxidase, $\mathrm{H}_{2} \mathrm{O}_{2}$ reacts with Amplex Red to produce resorufin.

\subsubsection{Materials}

- $\quad$ GPL-PLD from Streptomyces sp. (T-39, Asahi Kasei Pharma, Tokyo, Japan).

- Choline oxidase from Alcaligenes sp. (037-14401, FUJIFILM Wako Pure Chemical, Osaka, Japan).

- Peroxidase from horseradish roots (46261003, Oriental Yeast, Tokyo, Japan).

- Amplex Red (A12222, Thermo Fisher Scientific, Waltham, MA, USA).

- Amplex Red/UltraRed Stop Reagent (A33855, Thermo Fisher Scientific).

- $\quad$ Egg PC (L- $\alpha$-PC from chicken egg) (840051P, Avanti Polar Lipids, Alabaster, AL, USA).

- 96-well black flatbottom plate S type for fluorescence measurements (MS-8496K, Sumitomo Bakelite, Tokyo, Japan).

- $\quad$ Triton X-100 (see Section 6.2.1).

\subsubsection{Reagents}

- $\quad$ Reagent C1: $100 \mathrm{U} / \mathrm{mL}$ GPL-PLD, $1.5 \mathrm{mM} \mathrm{CaCl}_{2}, 50 \mathrm{mM} \mathrm{NaCl}$, and $50 \mathrm{mM}$ Tris-HCl (pH 7.4).

- Reagent C2: $4 \mathrm{U} / \mathrm{mL}$ choline oxidase, $5 \mathrm{U} / \mathrm{mL}$ peroxidase, $300 \mu \mathrm{M}$ Amplex Red, $0.2 \%$ Triton X-100, $50 \mathrm{mM} \mathrm{NaCl}$, and $50 \mathrm{mM}$ Tris- $\mathrm{HCl}$ (pH 7.4).

- Solubilize egg PC (average M.W. 770.12) at $25 \mathrm{mM}$ in 10\% Triton X-100 aqueous solution, and then dilute with water to $2.5 \mathrm{mM}$ in $1 \%$ Triton X-100 solution. To prepare PC standard solutions, $2.5 \mathrm{mM}$ egg PC in 1\% Triton X-100 is sequentially diluted with $1 \%$ Triton X-100 solution. The $25 \mathrm{mM}$ egg PC in $10 \%$ Triton $\mathrm{X}-100$ solution is stored at $-20^{\circ} \mathrm{C}$.

\subsubsection{Procedure}

1. Pipette each sample or PC standard solution $(10 \mu \mathrm{L})$ into a 96-well black plate.

2. Add Reagent $\mathrm{C} 1(40 \mu \mathrm{L})$ to each well and incubate at $37^{\circ} \mathrm{C}$ for $30 \mathrm{~min}$.

3. Add Reagent $\mathrm{C} 2(50 \mu \mathrm{L})$ to each well and incubate at room temperature for $30 \mathrm{~min}$.

4. Add Amplex Red Stop Reagent $(20 \mu \mathrm{L})$ to each well.

5. Measure the fluorescence intensity at $544 \mathrm{~nm}$ (excitation) and $590 \mathrm{~nm}$ (emission) using a microplate reader (Infinite M200, Tecan, Männedorf, Switzerland).

\subsubsection{Sensitivity and Specificity}

The standard curve for the PC measurement is quadratic at concentrations below $20 \mu \mathrm{M}$ and linear between 20 and $150 \mu \mathrm{M}$ [18]. The detection limit is $1 \mu \mathrm{M}$ (10 pmol in the reaction mixture). There are no differences in the fluorescence changes in response to egg PC, soy PC, 1-palmitoyl-2-oleoyl $\mathrm{PC}$, and plasmanylcholine, indicating that this PC measurement is not affected by the chain length, the number of double bonds or the linkage type (ester or ether). In this PC assay, other choline-containing phospholipids, SM, and LPC, induce only negligible increases in fluorescence. In the recovery test using the cellular lipid extract, the mean recovery of 1-palmitoyl-2-oleoyl PC in concentrations of $12.5-75.0 \mu \mathrm{M}$ is $101.3 \%$, indicating that there is no interference of hydrophobic compounds extracted from the cells [18].

\subsection{Protocol for Enzymatic Fluorometric Measurement of PE}

\subsubsection{Strategy}

There are three reaction steps for the enzymatic fluorometric measurement of PE [18] (Figure 3b).

1. PE is hydrolyzed by PLD to ethanolamine and PA. 
2. Ethanolamine is oxidized by amine oxidase, generating $\mathrm{H}_{2} \mathrm{O}_{2}, \mathrm{NH}_{3}$ and glycolaldehyde.

3. In the presence of peroxidase, $\mathrm{H}_{2} \mathrm{O}_{2}$ reacts with Amplex Red to produce resorufin.

\subsubsection{Materials}

- $\quad$ PLD from Streptomyces chromofuscus (BML-SE301, Enzo Life Sciences, Farmingdale, NY, USA).

- Amine oxidase (tyramine oxidase) from Arthrobacter sp. (T-25, Asahi Kasei Pharma).

- $\quad$ Liver PE (L- $\alpha$-PE from bovine liver) (840026P, Avanti Polar Lipids).

- Triton X-100 (see Section 6.2.1). Peroxidase, Amplex Red, Amplex Red/UltraRed Stop Reagent, and 96-well black flatbottom plate (see Section 6.3.2).

\subsubsection{Reagents}

- $\quad$ Reagent E1: $150 \mathrm{U} / \mathrm{mL}$ PLD, $1.5 \mathrm{mM} \mathrm{CaCl}_{2}, 50 \mathrm{mM} \mathrm{NaCl}$, and $50 \mathrm{mM}$ Tris-HCl (pH 7.4).

- Reagent E2: $8 \mathrm{U} / \mathrm{mL}$ amine oxidase, $5 \mathrm{U} / \mathrm{mL}$ peroxidase, $300 \mu \mathrm{M}$ Amplex Red, 0.2\% Triton X-100, $50 \mathrm{mM} \mathrm{NaCl}$, and $50 \mathrm{mM}$ Tris- $\mathrm{HCl}$ (pH 7.4).

- Solubilize liver PE (average M.W. 756.34) at $25 \mathrm{mM}$ in 10\% Triton X-100 aqueous solution, and then dilute with water to $2.5 \mathrm{mM}$ in $1 \%$ Triton X-100 solution. To prepare PE standard solutions, $2.5 \mathrm{mM}$ liver PE in 1\% Triton X-100 is sequentially diluted with $1 \%$ Triton X-100 solution. The $25 \mathrm{mM}$ liver $\mathrm{PE}$ in $10 \%$ Triton $\mathrm{X}-100$ solution is stored at $-20^{\circ} \mathrm{C}$.

\subsubsection{Procedure}

1. Pipette each sample or PE standard solution $(10 \mu \mathrm{L})$ into a 96 -well black plate.

2. Add Reagent $\mathrm{E} 1(40 \mu \mathrm{L})$ to each well and incubate at $37^{\circ} \mathrm{C}$ for $30 \mathrm{~min}$.

3. Add Reagent E2 $(50 \mu \mathrm{L})$ to each well and incubate at room temperature for $30 \mathrm{~min}$.

4. Add Amplex Red Stop Reagent $(20 \mu \mathrm{L})$ to each well.

5. Measure the fluorescence intensity at $544 \mathrm{~nm}$ (excitation) and $590 \mathrm{~nm}$ (emission) using a microplate reader.

\subsubsection{Sensitivity and Specificity}

The standard curve for the PE measurement is quadratic at concentrations below $50 \mu \mathrm{M}$ and linear between 50 and $250 \mu \mathrm{M}$ [18]. The detection limit is $1 \mu \mathrm{M}$ (10 pmol in the reaction mixture). There are no differences in the fluorescence changes in response to liver PE, soy PE, 1-palmitoyl-2-oleoyl PE, plasmenylethanolamine, and LPE, indicating that this PE measurement is not affected by the chain length, the number of double bonds, or the linkage type (ester or ether), and does not distinguish between PE and LPE. In this PE assay, other amine-containing phospholipids, PC and PS, lead to no increase in fluorescence. In the recovery test using the cellular lipid extract, the mean recovery of 1-palmitoyl-2-oleoyl PE in concentrations of $12.5-75.0 \mu \mathrm{M}$ is $99.6 \%$ [18].

\subsection{Protocol for Enzymatic Fluorometric Measurement of PS}

\subsubsection{Strategy}

There are three reaction steps for the enzymatic fluorometric measurement of PS [21] (Figure 3c).

1. PS is hydrolyzed by PLD to serine and PA.

2. Serine is oxidized by L-amino acid oxidase, generating $\mathrm{H}_{2} \mathrm{O}_{2}$ and 2-oxo-3-hydroxypropionic acid.

3. In the presence of peroxidase, $\mathrm{H}_{2} \mathrm{O}_{2}$ reacts with Amplex Red to produce resorufin.

\subsubsection{Materials}

- $\quad$ PLD from Streptomyces chromofuscus (BML-SE301, Enzo Life Sciences). 
- L-Amino acid oxidase from Crotalus adamanteus venom (LAO, Worthington Biochemical, Lakewood, NJ, USA).

- $\quad$ Brain PS (L- $\alpha$-PS sodium salt from porcine brain) (840032P, Avanti Polar Lipids).

- Triton X-100 (see Section 6.2.1). Peroxidase, Amplex Red, Amplex Red/UltraRed Stop Reagent, and 96-well black flatbottom plate (see Section 6.3.2).

\subsubsection{Reagents}

- Reagent S1: $600 \mathrm{U} / \mathrm{mL}$ PLD, $25 \mathrm{U} / \mathrm{mL}$ L-amino acid oxidase, $50 \mathrm{mM} \mathrm{NaCl}$, and $50 \mathrm{mM}$ Tris-HCl ( $\mathrm{pH}$ 7.4).

- Reagent S2: $6.25 \mathrm{U} / \mathrm{mL}$ peroxidase, $187.5 \mu \mathrm{M}$ Amplex Red, 0.125\% Triton X-100, $50 \mathrm{mM} \mathrm{NaCl}$, and $50 \mathrm{mM}$ Tris- $\mathrm{HCl}$ (pH 7.4).

- Solubilize brain PS (average M.W. 824.97) at $25 \mathrm{mM}$ in 10\% Triton X-100 aqueous solution, and then dilute with water to $2.5 \mathrm{mM}$ in $1 \%$ Triton X-100 solution. To prepare PS standard solutions, $2.5 \mathrm{mM}$ brain PS in 1\% Triton X-100 is sequentially diluted with $1 \%$ Triton X-100 solution. The $25 \mathrm{mM}$ brain PS in $10 \%$ Triton $\mathrm{X}-100$ solution is stored at $-20{ }^{\circ} \mathrm{C}$.

\subsubsection{Procedure}

1. Pipette each sample or PS standard solution $(10 \mu \mathrm{L})$ into a 96-well black plate.

2. Add Reagent $\mathrm{S} 1(10 \mu \mathrm{L})$ to each well and incubate at $25^{\circ} \mathrm{C}$ for $240 \mathrm{~min}$.

3. Add Reagent $\mathrm{S} 2(80 \mu \mathrm{L})$ to each well and incubate at room temperature for $15 \mathrm{~min}$.

4. Add Amplex Red Stop Reagent $(20 \mu \mathrm{L})$ to each well.

5. Measure the fluorescence intensity at $544 \mathrm{~nm}$ (excitation) and $590 \mathrm{~nm}$ (emission) using a microplate reader.

\subsubsection{Sensitivity and Specificity}

The standard curve for the PS measurement is linear at concentrations below $50 \mu \mathrm{M}$ and hyperbolic between 50 and $1000 \mu \mathrm{M}$ [21]. The detection limit is $5 \mu \mathrm{M}$ (50 pmol in the reaction mixture). There are no differences in the fluorescence changes in response to brain PS, soy PS, 1-palmitoyl-2-oleoyl PS, and LPS, indicating that this PS measurement is not affected by the chain length or the number of double bonds, and does not distinguish between PS and LPS. In this PS assay, other amine-containing phospholipids, PC and PE, lead to no increase in fluorescence. In the recovery test using the cellular lipid extract, the mean recovery of 1-palmitoyl-2-oleoyl PS in concentrations of $25-125 \mu \mathrm{M}$ is $98.6 \%$ [21]. This PS enzymatic fluorometric assay and TLC-phosphorus assay correlate well [21].

\subsection{Protocol for Enzymatic Fluorometric Measurement of PA}

\subsubsection{Strategy}

There are three reaction steps for the enzymatic fluorometric measurement of PA [20] (Figure 3d).

1. PA is hydrolyzed by lipase to G3P and two fatty acids.

2. G3P is oxidized by G3P oxidase, generating $\mathrm{H}_{2} \mathrm{O}_{2}$ and dihydroxyacetone phosphate.

3. In the presence of peroxidase, $\mathrm{H}_{2} \mathrm{O}_{2}$ reacts with Amplex Red to produce resorufin.

\subsubsection{Materials}

- $\quad$ Lipase (lipoprotein lipase) from Pseudomonas sp. (129-04501, FUJIFILM Wako Pure Chemical).

- $\quad$ G3P oxidase (L- $\alpha$-glycerophosphate oxidase) from Streptococcus sp. (T-60, Asahi Kasei Pharma).

- $\quad$ Egg PA (L- $\alpha$-PA sodium salt from chicken egg) (840101P, Avanti Polar Lipids).

- The 0.2-ml PCR tube with a flat cap (FG-021F, NIPPON Genetics, Tokyo, Japan). 
- Triton X-100 (see Section 6.2.1). Peroxidase, Amplex Red, Amplex Red/UltraRed Stop Reagent, and 96-well black flatbottom plate (see Section 6.3.2).

\subsubsection{Reagents}

- $\quad$ Reagent A1: 40,000 U/mL lipase, $50 \mathrm{mM} \mathrm{NaCl}$, and $50 \mathrm{mM}$ Tris- $\mathrm{HCl}$ (pH 7.4).

- Reagent A2: $10 \mathrm{U} / \mathrm{mL}$ G3P oxidase, $5 \mathrm{U} / \mathrm{mL}$ peroxidase, $300 \mu \mathrm{M}$ Amplex Red, $0.2 \%$ Triton X-100, $50 \mathrm{mM} \mathrm{NaCl}$, and $50 \mathrm{mM}$ Tris- $\mathrm{HCl}$ (pH 7.4).

- Solubilize egg PA (average M.W. 706.16) at $25 \mathrm{mM}$ in 10\% Triton X-100 aqueous solution, and then dilute with water to $2.5 \mathrm{mM}$ in $1 \%$ Triton X-100 solution. To prepare PA standard solutions, $2.5 \mathrm{mM}$ egg PA in $1 \%$ Triton X-100 is sequentially diluted with $1 \%$ Triton X-100 solution. The $25 \mathrm{mM}$ egg PA in $10 \%$ Triton $\mathrm{X}-100$ solution is stored at $-20{ }^{\circ} \mathrm{C}$.

\subsubsection{Procedure}

1. Pipette each sample or PA standard solution $(20 \mu \mathrm{L})$ into a $0.2-\mathrm{ml}$ tube.

2. Add Reagent $\mathrm{A} 1(80 \mu \mathrm{L})$ to each tube, incubate at $37^{\circ} \mathrm{C}$ for $30 \mathrm{~min}$, and then heat at $96{ }^{\circ} \mathrm{C}$ for 3 min using a thermal cycler.

3. Precipitate the denatured enzyme by centrifugation $(7200 \times g, 5 \mathrm{~min}$, room temperature).

4. Pipette the supernatant $(50 \mu \mathrm{L})$ into a 96-well black plate.

5. Add Reagent $\mathrm{A} 2(50 \mu \mathrm{L})$ to each well and incubate at room temperature for $30 \mathrm{~min}$.

6. Add Amplex Red Stop Reagent $(20 \mu \mathrm{L})$ to each well.

7. Measure the fluorescence intensity at $544 \mathrm{~nm}$ (excitation) and $590 \mathrm{~nm}$ (emission) using a microplate reader.

\subsubsection{Sensitivity and Specificity}

The standard curve for the PA measurement is quadratic at concentrations below $50 \mu \mathrm{M}$ and linear between 50 and $250 \mu \mathrm{M}$ [20]. The detection limit is $5 \mu \mathrm{M}$ (50 pmol in the reaction mixture). There are no differences in the fluorescence changes in response to egg PA and LPA, indicating that this PA measurement is not affected by the chain length or the number of double bonds, and does not distinguish between PA and LPA.

\subsection{Protocol for Enzymatic Fluorometric Measurement of PI}

\subsubsection{Strategy}

There are four reaction steps for the enzymatic fluorometric measurement of PI [24] (Figure 3e).

1. PI is hydrolyzed by PLD to myo-inositol and PA.

2. The oxidation of myo-inositol and the reduction of $\mathrm{NAD}^{+}$are catalyzed by myo-inositol dehydrogenase, generating scyllo-inosose and $\mathrm{NADH}$, respectively.

3. NADH is oxidized by NADH oxidase, generating $\mathrm{H}_{2} \mathrm{O}_{2}$ and $\mathrm{NAD}^{+}$.

4. In the presence of peroxidase, $\mathrm{H}_{2} \mathrm{O}_{2}$ reacts with Amplex Red to produce resorufin.

\subsubsection{Materials}

- $\quad$ PLD from Streptomyces chromofuscus (T-222, Asahi Kasei Pharma).

- $\quad m y o-I n o s i t o l ~ d e h y d r o g e n a s e$ from Bacillus subtilis (E-INDHBS, Megazyme, Bray, Ireland).

- $\quad$ NADH oxidase from Bacillus licheniformis (23626-52, Nacalai Tesque, Kyoto, Japan).

- $\quad \mathrm{NAD}^{+}$( $\beta$-nicotinamide adenine dinucleotide) (24338-31, Nacalai Tesque).

- $\quad$ Liver PI (L- $\alpha$-PI sodium salt from bovine liver) (840042P, Avanti Polar Lipids).

- Triton X-100 (see Section 6.2.1). Peroxidase, Amplex Red, Amplex Red/UltraRed Stop Reagent, and 96-well black flatbottom plate (see Section 6.3.2). 0.2-mL tube (see Section 6.6.2). 


\subsubsection{Reagents}

- $\quad$ Reagent I1: 200 units/mL PLD, $2.4 \mathrm{mM} \mathrm{CaCl}_{2}, 50 \mathrm{mM} \mathrm{NaCl}$, and $50 \mathrm{mM}$ Tris- $\mathrm{HCl}$ (pH 7.4).

- Reagent I2: 25 units/mL myo-inositol dehydrogenase, $10 \mathrm{mM} \mathrm{NAD}^{+}, 150 \mathrm{mM} \mathrm{NaCl}$, and $150 \mathrm{mM}$ Tris- $\mathrm{HCl}(\mathrm{pH} 7.4)$.

- Reagent I3: $1 \mathrm{U} / \mathrm{mL}$ NADH oxidase, 6.25 units/mL peroxidase, $187.5 \mu \mathrm{M}$ Amplex Red, $0.125 \%$ Triton X-100, $50 \mathrm{mM} \mathrm{NaCl}$, and $50 \mathrm{mM}$ Tris- $\mathrm{HCl}$ (pH 7.4).

- Solubilize liver PI (average M.W. 902.13) at $25 \mathrm{mM}$ in 10\% Triton X-100 aqueous solution, and then dilute with water to $2.5 \mathrm{mM}$ in $1 \%$ Triton X-100 solution. To prepare PI standard solutions, $2.5 \mathrm{mM}$ liver PI in $1 \%$ Triton X-100 is sequentially diluted with $1 \%$ Triton X-100 solution. The $25 \mathrm{mM}$ liver PI in $10 \%$ Triton $\mathrm{X}-100$ solution is stored at $-20^{\circ} \mathrm{C}$.

\subsubsection{Procedure}

1. Pipette each sample or PI standard solution $(10 \mu \mathrm{L})$ into a $0.2-\mathrm{mL}$ tube.

2. Add Reagent I $1(10 \mu \mathrm{L})$ to each tube, incubate at $37^{\circ} \mathrm{C}$ for $60 \mathrm{~min}$, and then heat at $96^{\circ} \mathrm{C}$ for $3 \mathrm{~min}$ using a thermal cycler.

3. Precipitate the denatured enzyme by centrifugation $(7200 \times g, 5 \mathrm{~min}$, room temperature).

4. Pipette the supernatant $(10 \mu \mathrm{L})$ into a 96 -well black plate.

5. Add Reagent I2 $(10 \mu \mathrm{L})$ to each well and incubate at $25^{\circ} \mathrm{C}$ for $120 \mathrm{~min}$.

6. Add Reagent $\mathrm{I} 3(80 \mu \mathrm{L})$ to each well and incubate at $45^{\circ} \mathrm{C}$ for $60 \mathrm{~min}$.

7. Add Amplex Red Stop Reagent $(20 \mu \mathrm{L})$ to each well.

8. Measure the fluorescence intensity at $544 \mathrm{~nm}$ (excitation) and $590 \mathrm{~nm}$ (emission) using a microplate reader.

\subsubsection{Sensitivity and Specificity}

The standard curve for the PI measurement is hyperbolic at concentrations below $500 \mu \mathrm{M}$ [24]. The detection limit is $2 \mu \mathrm{M}$ ( $20 \mathrm{pmol}$ in the reaction mixture). There are no differences in the fluorescence changes in response to liver PI, soy PI, 1,2-dioleoyl PI, 1-palmitoyl-2-oleoyl PI, LPI, PI(4)P, and PI(5)P, indicating that this PI measurement is not affected by the chain length or the number of double bonds, and does not distinguish among PI, LPI, PI(4)P, and PI(5)P. On the other hand, PI(3)P, PI(3,4) $\mathrm{P}_{2}$, $\mathrm{PI}(3,5) \mathrm{P}_{2}, \mathrm{PI}(4,5) \mathrm{P}_{2}$, and $\mathrm{PI}(3,4,5) \mathrm{P}_{3}$ exhibit no or negligible fluorescence increases. In this PI assay, PC, PE, PS, PA, PG, CL, and SM lead to no increase in fluorescence. In the recovery test using the cellular lipid extract, the mean recovery of liver PI in concentrations of $25-250 \mu \mathrm{M}$ is $99.8 \%$ [24]. Excellent linearity of the PI assay is obtained when the cellular lipid extract is serially diluted [24].

6.8. Protocol for Enzymatic Fluorometric Measurement of $P G+C L$

\subsubsection{Strategy}

There are five reaction steps for the enzymatic fluorometric measurement of PG + CL [23] (Figure 3f).

1. CL is hydrolyzed by PLD to PG and PA.

2. $\quad$ PG is hydrolyzed by PLD to glycerol and PA.

3. Glycerol is phosphorylated by glycerol kinase to G3P.

4. G3P is oxidized by G3P oxidase, generating $\mathrm{H}_{2} \mathrm{O}_{2}$ and dihydroxyacetone phosphate.

5. In the presence of peroxidase, $\mathrm{H}_{2} \mathrm{O}_{2}$ reacts with Amplex Red to produce resorufin.

6.8.2. Materials

- PLD from Streptomyces chromofuscus (T-222, Asahi Kasei Pharma).

- Glycerol kinase from Cellulomonas sp. (GYK-301, Toyobo, Osaka, Japan). 
- ATP (adenosine 5'-triphosphate disodium salt trihydrate) (018-16911, FUJIFILM Wako Pure Chemical).

- Heart CL (CL disodium salt from bovine heart) (840012P, Avanti Polar Lipids).

- Triton X-100 (see Section 6.2.1). Peroxidase, Amplex Red, Amplex Red Stop Reagent, and 96-well black flatbottom plate (see Section 6.2.1). G3P oxidase (see Section 6.6.2).

6.8.3. Reagents

- $\quad$ Reagent L1: $5 \mathrm{U} / \mathrm{mL}$ PLD, $1.5 \mathrm{mM} \mathrm{CaCl}_{2}, 50 \mathrm{mM} \mathrm{NaCl}$, and $50 \mathrm{mM}$ Tris- $\mathrm{HCl}$ (pH 7.4).

- Reagent L2: $5 \mathrm{U} / \mathrm{mL}$ glycerol kinase, $10 \mathrm{U} / \mathrm{mL}$ G3P oxidase, $5 \mathrm{U} / \mathrm{ml}$ peroxidase, $300 \mu \mathrm{M}$ Amplex Red, $4.5 \mathrm{mM}$ ATP, $2 \mathrm{mM} \mathrm{MgCl} 2,0.2 \%$ Triton X-100, $50 \mathrm{mM} \mathrm{NaCl}$, and $50 \mathrm{mM}$ Tris- $\mathrm{HCl}$ (pH 7.4).

- Solubilize heart CL (average M.W. 1494.32) at $25 \mathrm{mM}$ in 10\% Triton X-100 aqueous solution, and then dilute with water to $2.5 \mathrm{mM}$ in $1 \%$ Triton X-100 solution. To prepare CL standard solutions, $2.5 \mathrm{mM}$ heart CL in $1 \%$ Triton X-100 is sequentially diluted with $1 \%$ Triton X-100 solution. The $25 \mathrm{mM}$ heart $\mathrm{CL}$ in $10 \%$ Triton $\mathrm{X}-100$ solution is stored at $-20^{\circ} \mathrm{C}$.

\subsubsection{Procedure}

1. Pipette each sample or CL standard solution $(10 \mu \mathrm{L})$ into a 96-well black plate.

2. Add Reagent $\mathrm{L} 1(40 \mu \mathrm{L})$ to each well and incubate at $37^{\circ} \mathrm{C}$ for $30 \mathrm{~min}$.

3. Add Reagent L2 $(50 \mu \mathrm{L})$ to each well and incubate at room temperature for $30 \mathrm{~min}$.

4. Add Amplex Red Stop Reagent $(20 \mu \mathrm{L})$ to each well.

5. Measure the fluorescence intensity at $544 \mathrm{~nm}$ (excitation) and $590 \mathrm{~nm}$ (emission) using a microplate reader.

\subsubsection{Sensitivity and Specificity}

The standard curve for CL measurement is linear at concentrations below $150 \mu \mathrm{M}$ [23]. The detection limit is $1 \mu \mathrm{M}(10 \mathrm{pmol}$ in the reaction mixture). There are no differences in the fluorescence changes in response to heart CL, tetraoleoyl CL, egg PG, soy PG, 1-palmitoyl-2-oleoyl PG, and LPG, indicating that this measurement is not affected by the chain length or the number of double bonds, and does not distinguish among CL, PG, and LPG. Therefore, this assay quantifies the sum of PG and CL (PG + CL). In the recovery test using the cellular lipid extract, the mean recovery of heart CL in concentrations of $12.5-100 \mu \mathrm{M}$ is $100.2 \%$ [23]. Excellent linearity of the PG + CL assay is obtained when the cellular lipid extract is serially diluted [23].

\subsection{Protocol for Enzymatic Fluorometric Measurement of SM}

\subsubsection{Strategy}

There are four reaction steps for the enzymatic fluorometric measurement of SM [22] (Figure 3g).

1. $\mathrm{SM}$ is hydrolyzed by SMase to phosphocholine and ceramide.

2. Phosphocholine is dephosphorylated by alkaline phosphatase to choline.

3. Choline is oxidized by choline oxidase, generating two $\mathrm{H}_{2} \mathrm{O}_{2}$ molecules and betaine.

4. In the presence of peroxidase, $\mathrm{H}_{2} \mathrm{O}_{2}$ reacts with Amplex Red to produce resorufin.

\subsubsection{Materials}

- $\quad$ SMase from Bacillus cereus (S9396, Sigma-Aldrich, St. Louis, MO, USA).

- Alkaline phosphatase from calf intestine (47785055, Oriental Yeast).

- $\quad$ Egg SM (SM from chicken egg) (860061P, Avanti Polar Lipids).

- Triton X-100 (see Section 6.2.1). Choline oxidase, peroxidase, Amplex Red, Amplex Red/UltraRed Stop Reagent, and 96-well black flatbottom plate (see Section 6.3.2). 


\subsubsection{Reagents}

- $\quad$ Reagent M1: $1 \mathrm{U} / \mathrm{mL}$ SMase, $20 \mathrm{U} / \mathrm{mL}$ alkaline phosphatase, $1.5 \mathrm{mM} \mathrm{MgCl}$, $50 \mathrm{mM} \mathrm{NaCl}$, and $50 \mathrm{mM}$ Tris- $\mathrm{HCl}$ (pH 7.4).

- $\quad$ Reagent M2: $4 \mathrm{U} / \mathrm{mL}$ choline oxidase, $5 \mathrm{U} / \mathrm{mL}$ peroxidase, $300 \mu \mathrm{M}$ Amplex Red, 0.2\% Triton X-100, $50 \mathrm{mM} \mathrm{NaCl}$, and $50 \mathrm{mM}$ Tris- $\mathrm{HCl}$ (pH 7.4).

- $\quad$ Solubilize egg SM (average M.W. 710.70) at $25 \mathrm{mM}$ in 10\% Triton X-100 aqueous solution, and then dilute with water to $2.5 \mathrm{mM}$ in $1 \%$ Triton X-100 solution. To prepare SM standard solutions, $2.5 \mathrm{mM}$ egg SM in 1\% Triton X-100 is sequentially diluted with 1\% Triton X-100 solution. The $25 \mathrm{mM}$ egg $\mathrm{SM}$ in $10 \%$ Triton $\mathrm{X}-100$ solution is stored at $-20{ }^{\circ} \mathrm{C}$.

\subsubsection{Procedure}

1. Pipette each sample or SM standard solution $(10 \mu \mathrm{L})$ into a 96-well black plate.

2. Add Reagent $\mathrm{M} 1(40 \mu \mathrm{L})$ to each well and incubate at $37^{\circ} \mathrm{C}$ for $30 \mathrm{~min}$.

3. Add Reagent M2 $(50 \mu \mathrm{L})$ to each well and incubate at room temperature for $30 \mathrm{~min}$.

4. Add Amplex Red Stop Reagent $(20 \mu \mathrm{L})$ to each well.

5. Measure the fluorescence intensity at $544 \mathrm{~nm}$ (excitation) and $590 \mathrm{~nm}$ (emission) using a microplate reader.

\subsubsection{Sensitivity and Specificity}

The standard curve for the SM measurement is quadratic at concentrations below $10 \mu \mathrm{M}$ and linear between 10 and $100 \mu \mathrm{M}$ [22]. The detection limit is $0.5 \mu \mathrm{M}$ (5 pmol in the reaction mixture). There are no differences in the fluorescence changes in response to egg SM, brain SM, and palmitoyl $\mathrm{SM}$, indicating that this SM measurement is not affected by the chain length or the number of double bonds. In this SM assay, other choline-containing phospholipids, SPC, PC, and LPC, lead to no or negligible increases in fluorescence. In the recovery test using the cellular lipid extract, the mean recovery of palmitoyl SM in concentrations of $12.5-50 \mu \mathrm{M}$ is $100.3 \%$ [22]. Excellent linearity of the SM assay is obtained when the cellular lipid extract is serially diluted [22].

\section{Future Directions}

Our enzyme-based fluorometric methods enable simple and high-throughput, but not time-consuming, quantification of major phospholipid classes. All enzymes and compounds used in these assays are commercially available at present. These assays have high sensitivity and high accuracy (Table 1), and will be applied to cells, intracellular organelles, tissues, fluids, lipoproteins, and extracellular vesicles for elucidating physiological, pathological, and molecular mechanisms and for identifying disease biomarkers.

Table 1. Sensitivities and specificities of enzymatic fluorometric assays.

\begin{tabular}{ccc}
\hline Assay & Detection Limit (pmol) & Detectable Phospholipid Class \\
\hline PC assay & 10 & PC, plasmanylcholine \\
PE assay & 10 & PE, plasmenylethanolamine, LPE \\
PS assay & 50 & PS, LPS \\
PA assay & 50 & PA, LPA \\
PI assay & 20 & PI, LPI, PI(4)P, PI(5)P \\
PG + CL assay & 10 & PG, CL, LPG \\
SM assay & 5 & SM \\
\hline
\end{tabular}

These enzymatic fluorometric assays are more sensitive than the assays using TLC or HPLC. Mass spectrometry has extremely high sensitivity (femto-molar range) to detect phospholipid molecular species. However, it is difficult to quantify phospholipid classes using mass spectrometry. 
In addition, mass spectrometry takes a longer time to analyze many samples than the enzymatic assays. The combination of enzymatic fluorometric assays and mass spectrometry will make it possible to comprehensively characterize the phospholipid compositions in biological membranes. On the other hand, enzymatic fluorometric assays for measuring lysophospholipid classes still need to be developed.

Author Contributions: Writing-original draft preparation, S.-y.M.; writing-review and editing, T.T. (Tokuji Tsuji) and T.T. (Tomohiro Terada). All authors have read and agreed to the published version of the manuscript.

Funding: This work was supported in part by the PRIME from Japan Agency for Medical Research and Development (AMED), by JSPS KAKENHI grant number JP19K23799, and by a grant from the Research Foundation for Pharmaceutical Sciences.

Conflicts of Interest: The authors declare no conflict of interest.

\section{Abbreviations}

$\begin{array}{ll}\text { 4-AA } & \text { 4-amino antipyrine } \\ \text { ABC } & \text { ATP-binding cassette } \\ \text { CL } & \text { cardiolipin } \\ \text { DAOS } & \text { N-ethyl-N-(2-hydroxy-3-sulfopropyl)-3,5-dimethoxyaniline } \\ \text { ER } & \text { endoplasmic reticulum } \\ \text { G3P } & \text { glycerol-3-phosphate } \\ \text { GPL } & \text { glycerophospholipid } \\ \text { GPL-PLD } & \text { glycerophospholipid-specific phospholipase D } \\ \text { HDL } & \text { high density lipoprotein } \\ \text { HPLC } & \text { high-performance liquid chromatography } \\ \text { HPPA } & \text { 3-(4-hydroxyphenyl)propionic acid } \\ \text { LDL } & \text { low density lipoprotein } \\ \text { LPA } & \text { lysophosphatidic acid } \\ \text { LPC } & \text { lysophosphatidylcholine } \\ \text { LPE } & \text { lysophosphatidylethanolamine } \\ \text { LPG } & \text { lysophosphatidylglycerol } \\ \text { LPI } & \text { lysophosphatidylinositol } \\ \text { LPS } & \text { lysophosphatidylserine } \\ \text { Lp-X } & \text { lipoprotein-X } \\ \text { PA } & \text { phosphatidic acid } \\ \text { PC } & \text { phosphatidylcholine } \\ \text { PE } & \text { phosphatidylethanolamine } \\ \text { PG } & \text { phosphatidylglycerol } \\ \text { PI } & \text { phosphatidylinositol } \\ \text { PLD } & \text { phospholipase D } \\ \text { PS } & \text { phosphatidylserine } \\ \text { SM } & \text { sphingomyelin } \\ \text { SMase } & \text { sphingomyelinase } \\ \text { SPC } & \text { sphingosylphosphorylcholine } \\ \text { TLC } & \text { thin-layer chromatography } \\ \text { TOOS } & \text { N-ethyl-N-(2-hydroxy-3-sulfopropyl)-3-methylaniline } \\ \text { VLDL } & \text { very low density lipoprotein } \\ & \end{array}$

\section{References}

1. Miyahara, K.; Kasahara, N.; Kondo, Y.; Imai, Y.; Matuzaki, F. Changes in plasma lipids and abnormal lipoproteins in a patient with drug-induced cholestatic hepatitis. Jpn. J. Med. 1991, 30, 354-359. [CrossRef]

2. Foster, D.A.; Xu, L. Phospholipase D in cell proliferation and cancer. Mol. Cancer Res. 2003, 1, 789-800. [PubMed]

3. Whitsett, J.A.; Wert, S.E.; Weaver, T.E. Alveolar surfactant homeostasis and the pathogenesis of pulmonary disease. Annu. Rev. Med. 2010, 61, 105-119. [CrossRef] [PubMed] 
4. Claypool, S.M.; Koehler, C.M. The complexity of cardiolipin in health and disease. Trends Biochem. Sci. 2012, 37, 32-41. [CrossRef] [PubMed]

5. Martinez-Beamonte, R.; Lou-Bonafonte, J.M.; Martinez-Gracia, M.V.; Osada, J. Sphingomyelin in high-density lipoproteins: Structural role and biological function. Int. J. Mol. Sci. 2013, 14, 7716-7741. [CrossRef] [PubMed]

6. Morita, S.Y. Metabolism and modification of apolipoprotein B-containing lipoproteins involved in dyslipidemia and atherosclerosis. Biol. Pharm. Bull. 2016, 39, 1-24. [CrossRef]

7. Epand, R.M. Features of the phosphatidylinositol cycle and its role in signal transduction. J. Membr. Biol. 2017, 250, 353-366. [CrossRef]

8. Morita, S.Y.; Ikeda, Y.; Tsuji, T.; Terada, T. Molecular mechanisms for protection of hepatocytes against bile salt cytotoxicity. Chem. Pharm. Bull. 2019, 67, 333-340. [CrossRef]

9. Fellin, R.; Manzato, E. Lipoprotein-X fifty years after its original discovery. Nutr. Metab. Cardiovasc. Dis. 2019, 29, 4-8. [CrossRef]

10. Pujol-Lereis, L.M. Alteration of sphingolipids in biofluids: Implications for neurodegenerative diseases. Int. J. Mol. Sci. 2019, 20, 3564. [CrossRef]

11. Skipski, V.P.; Peterson, R.F.; Barclay, M. Quantitative analysis of phospholipids by thin-layer chromatography. Biochem. J. 1964, 90, 374-378. [CrossRef] [PubMed]

12. Lutzke, B.S.; Braughler, J.M. An improved method for the identification and quantitation of biological lipids by HPLC using laser light-scattering detection. J. Lipid Res. 1990, 31, 2127-2130. [PubMed]

13. Stith, B.J.; Hall, J.; Ayres, P.; Waggoner, L.; Moore, J.D.; Shaw, W.A. Quantification of major classes of Xenopus phospholipids by high performance liquid chromatography with evaporative light scattering detection. J. Lipid Res. 2000, 41, 1448-1454. [PubMed]

14. Ramos, R.G.; Libong, D.; Rakotomanga, M.; Gaudin, K.; Loiseau, P.M.; Chaminade, P. Comparison between charged aerosol detection and light scattering detection for the analysis of Leishmania membrane phospholipids. J. Chromatogr. A 2008, 1209, 88-94. [CrossRef] [PubMed]

15. Taguchi, R.; Hayakawa, J.; Takeuchi, Y.; Ishida, M. Two-dimensional analysis of phospholipids by capillary liquid chromatography/electrospray ionization mass spectrometry. J. Mass Spectrom. 2000, 35, 953-966. [CrossRef]

16. Taguchi, R.; Houjou, T.; Nakanishi, H.; Yamazaki, T.; Ishida, M.; Imagawa, M.; Shimizu, T. Focused lipidomics by tandem mass spectrometry. J. Chromatogr. B Analyt. Technol. Biomed. Life Sci. 2005, 823, 26-36. [CrossRef]

17. Wakelam, M.J.; Pettitt, T.R.; Postle, A.D. Lipidomic analysis of signaling pathways. Methods Enzymol. 2007, 432, 233-246.

18. Morita, S.Y.; Takeuchi, A.; Kitagawa, S. Functional analysis of two isoforms of phosphatidylethanolamine N-methyltransferase. Biochem. J. 2010, 432, 387-398. [CrossRef]

19. Morita, S.Y.; Ikeda, N.; Horikami, M.; Soda, K.; Ishihara, K.; Teraoka, R.; Terada, T.; Kitagawa, S. Effects of phosphatidylethanolamine $\mathrm{N}$-methyltransferase on phospholipid composition, microvillus formation and bile salt resistance in LLC-PK1 cells. FEBS J. 2011, 278, 4768-4781. [CrossRef]

20. Morita, S.Y.; Ueda, K.; Kitagawa, S. Enzymatic measurement of phosphatidic acid in cultured cells. J. Lipid Res. 2009, 50, 1945-1952. [CrossRef]

21. Morita, S.Y.; Shirakawa, S.; Kobayashi, Y.; Nakamura, K.; Teraoka, R.; Kitagawa, S.; Terada, T. Enzymatic measurement of phosphatidylserine in cultured cells. J. Lipid Res. 2012, 53, 325-330. [CrossRef]

22. Morita, S.Y.; Soda, K.; Teraoka, R.; Kitagawa, S.; Terada, T. Specific and sensitive enzymatic measurement of sphingomyelin in cultured cells. Chem. Phys. Lipids 2012, 165, 571-576. [CrossRef]

23. Morita, S.Y.; Terada, T. Enzymatic measurement of phosphatidylglycerol and cardiolipin in cultured cells and mitochondria. Sci. Rep. 2015, 5, 11737. [CrossRef]

24. Tsuji, T.; Morita, S.Y.; Ikeda, Y.; Terada, T. Enzymatic fluorometric assays for quantifying all major phospholipid classes in cells and intracellular organelles. Sci. Rep. 2019, 9, 8607. [CrossRef]

25. Engin, A. Fat cell and fatty acid turnover in obesity. Adv. Exp. Med. Biol. 2017, 960, 135-160.

26. Vance, J.E. Phosphatidylserine and phosphatidylethanolamine in mammalian cells: Two metabolically related aminophospholipids. J. Lipid Res. 2008, 49, 1377-1387. [CrossRef] [PubMed]

27. Ramstedt, B.; Slotte, J.P. Sphingolipids and the formation of sterol-enriched ordered membrane domains. Biochim. Biophys. Acta 2006, 1758, 1945-1956. [CrossRef] [PubMed]

28. Horvath, S.E.; Daum, G. Lipids of mitochondria. Prog. Lipid Res. 2013, 52, 590-614. [CrossRef] 
29. Segawa, K.; Nagata, S. An apoptotic 'eat me' signal: Phosphatidylserine exposure. Trends Cell Biol. 2015, 25, 639-650. [CrossRef] [PubMed]

30. Zhu, J.; Wang, K.Z.; Chu, C.T. After the banquet: Mitochondrial biogenesis, mitophagy, and cell survival. Autophagy 2013, 9, 1663-1676. [CrossRef]

31. Avila-Flores, A.; Santos, T.; Rincon, E.; Merida, I. Modulation of the mammalian target of rapamycin pathway by diacylglycerol kinase-produced phosphatidic acid. J. Biol. Chem. 2005, 280, 10091-10099. [CrossRef] [PubMed]

32. Scherer, M.; Schmitz, G. Metabolism, function and mass spectrometric analysis of bis(monoacylglycero)phosphate and cardiolipin. Chem. Phys. Lipids 2011, 164, 556-562. [CrossRef] [PubMed]

33. Balla, T. Phosphoinositides: Tiny lipids with giant impact on cell regulation. Physiol. Rev. 2013, 93, 1019-1137. [CrossRef]

34. Yokoyama, S. Assembly of high-density lipoprotein. Arterioscler. Thromb. Vasc. Biol. 2006, 26, $20-27$. [CrossRef] [PubMed]

35. Nagao, K.; Tomioka, M.; Ueda, K. Function and regulation of ABCA1-membrane meso-domain organization and reorganization. FEBS J. 2011, 278, 3190-3203. [CrossRef] [PubMed]

36. Ben-Yashar, V.; Barenholz, Y. Characterization of the core and surface of human plasma lipoproteins. A study based on the use of five fluorophores. Chem. Phys. Lipids 1991, 60, 1-14. [CrossRef]

37. Morita, S.Y.; Okuhira, K.; Tsuchimoto, N.; Vertut-Doi, A.; Saito, H.; Nakano, M.; Handa, T. Effects of sphingomyelin on apolipoprotein E- and lipoprotein lipase-mediated cell uptake of lipid particles. Biochim. Biophys. Acta 2003, 1631, 169-176. [CrossRef]

38. Morita, S.Y.; Kawabe, M.; Sakurai, A.; Okuhira, K.; Vertut-Doi, A.; Nakano, M.; Handa, T. Ceramide in lipid particles enhances heparan sulfate proteoglycan and low density lipoprotein receptor-related protein-mediated uptake by macrophages. J. Biol. Chem. 2004, 279, 24355-24361. [CrossRef]

39. Morita, S.Y.; Nakano, M.; Sakurai, A.; Deharu, Y.; Vertut-Doi, A.; Handa, T. Formation of ceramide-enriched domains in lipid particles enhances the binding of apolipoprotein E. FEBS Lett. 2005, 579, 1759-1764. [CrossRef]

40. Ikeda, Y.; Morita, S.Y.; Terada, T. Cholesterol attenuates cytoprotective effects of phosphatidylcholine against bile salts. Sci. Rep. 2017, 7, 306. [CrossRef]

41. Morita, S.Y.; Terada, T. Molecular mechanisms for biliary phospholipid and drug efflux mediated by ABCB4 and bile salts. BioMed Res. Int. 2014, 2014, 954781. [CrossRef] [PubMed]

42. Morita, S.Y.; Kobayashi, A.; Takanezawa, Y.; Kioka, N.; Handa, T.; Arai, H.; Matsuo, M.; Ueda, K. Bile salt-dependent efflux of cellular phospholipids mediated by ATP binding cassette protein B4. Hepatology 2007, 46, 188-199. [CrossRef]

43. Morita, S.Y.; Tsuda, T.; Horikami, M.; Teraoka, R.; Kitagawa, S.; Terada, T. Bile salt-stimulated phospholipid efflux mediated by ABCB4 localized in nonraft membranes. J. Lipid Res. 2013, 54, 1221-1230. [CrossRef] [PubMed]

44. Ikeda, Y.; Morita, S.Y.; Hatano, R.; Tsuji, T.; Terada, T. Enhancing effect of taurohyodeoxycholate on ABCB4-mediated phospholipid efflux. Biochim. Biophys. Acta Mol. Cell Biol. Lipids 2019, 1864, 1495-1502. [CrossRef]

45. Batenburg, J.J.; Haagsman, H.P. The lipids of pulmonary surfactant: Dynamics and interactions with proteins. Prog. Lipid Res. 1998, 37, 235-276. [CrossRef]

46. Voelker, D.R.; Numata, M. Phospholipid regulation of innate immunity and respiratory viral infection. J. Biol. Chem. 2019, 294, 4282-4289. [CrossRef] [PubMed]

47. Ban, N.; Matsumura, Y.; Sakai, H.; Takanezawa, Y.; Sasaki, M.; Arai, H.; Inagaki, N. ABCA3 as a lipid transporter in pulmonary surfactant biogenesis. J. Biol. Chem. 2007, 282, 9628-9634. [CrossRef]

48. Yamamoto, T.; Kosaka, N.; Ochiya, T. Latest advances in extracellular vesicles: From bench to bedside. Sci. Technol. Adv. Mater. 2019, 20, 746-757. [CrossRef]

49. Woith, E.; Fuhrmann, G.; Melzig, M.F. Extracellular vesicles-connecting kingdoms. Int. J. Mol. Sci. 2019, 20, 5695. [CrossRef]

50. Meldolesi, J. Exosomes and ectosomes in intercellular communication. Curr. Biol. 2018, 28, R435-R444. [CrossRef] 
51. Record, M.; Carayon, K.; Poirot, M.; Silvente-Poirot, S. Exosomes as new vesicular lipid transporters involved in cell-cell communication and various pathophysiologies. Biochim. Biophys. Acta 2014, 1841, 108-120. [CrossRef] [PubMed]

52. Skotland, T.; Hessvik, N.P.; Sandvig, K.; Llorente, A. Exosomal lipid composition and the role of ether lipids and phosphoinositides in exosome biology. J. Lipid Res. 2019, 60, 9-18. [CrossRef] [PubMed]

53. Takayama, M.; Itoh, S.; Nagasaki, T.; Tanimizu, I. A new enzymatic method for determination of serum choline-containing phospholipids. Clin. Chim. Acta 1977, 79, 93-98. [PubMed]

54. Blaton, V.; De Buyzere, M.; Spincemaille, J.; Declercq, B. Enzymic assay for phosphatidylcholine and sphingomyelin in serum. Clin. Chem. 1983, 29, 806-809. [CrossRef] [PubMed]

55. Seidel, D.; Alaupovic, P.; Furman, R.H. A lipoprotein characterizing obstructive jaundice. I. Method for quantitative separation and identification of lipoproteins in jaundiced subjects. J. Clin. Investig. 1969, 48, 1211-1223. [CrossRef]

56. Seidel, D.; Alaupovic, P.; Furman, R.H.; McConathy, W.J. A lipoprotein characterizing obstructive jaundice. II. Isolation and partial characterization of the protein moieties of low density lipoproteins. J. Clin. Investig. 1970, 49, 2396-2407. [CrossRef]

57. Suzuki, L.; Hirayama, S.; Fukui, M.; Sasaki, M.; Hiroi, S.; Ayaori, M.; Terai, S.; Tozuka, M.; Watada, H.; Miida, T. Lipoprotein-X in cholestatic patients causes xanthomas and promotes foam cell formation in human macrophages. J. Clin. Lipidol. 2017, 11, 110-118. [CrossRef]

58. Elferink, R.P.; Ottenhoff, R.; van Marle, J.; Frijters, C.M.; Smith, A.J.; Groen, A.K. Class III P-glycoproteins mediate the formation of lipoprotein $X$ in the mouse. J. Clin. Investig. 1998, 102, 1749-1757. [CrossRef] [PubMed]

59. Jiang, X.C.; Paultre, F.; Pearson, T.A.; Reed, R.G.; Francis, C.K.; Lin, M.; Berglund, L.; Tall, A.R. Plasma sphingomyelin level as a risk factor for coronary artery disease. Arterioscler. Thromb. Vasc. Biol. 2000, 20, 2614-2618. [CrossRef] [PubMed]

60. Schissel, S.L.; Jiang, X.; Tweedie-Hardman, J.; Jeong, T.; Camejo, E.H.; Najib, J.; Rapp, J.H.; Williams, K.J.; Tabas, I. Secretory sphingomyelinase, a product of the acid sphingomyelinase gene, can hydrolyze atherogenic lipoproteins at neutral $\mathrm{pH}$. Implications for atherosclerotic lesion development. J. Biol. Chem. 1998, 273, 2738-2746. [CrossRef] [PubMed]

61. Marathe, S.; Choi, Y.; Leventhal, A.R.; Tabas, I. Sphingomyelinase converts lipoproteins from apolipoprotein E knockout mice into potent inducers of macrophage foam cell formation. Arterioscler. Thromb. Vasc. Biol. 2000, 20, 2607-2613. [CrossRef] [PubMed]

62. Allain, C.C.; Poon, L.S.; Chan, C.S.; Richmond, W.; Fu, P.C. Enzymatic determination of total serum cholesterol. Clin. Chem. 1974, 20, 470-475. [CrossRef] [PubMed]

63. Shimizu, S.; Tani, Y.; Yamada, H.; Tabata, M.; Murachi, T. Enzymatic determination of serum-free fatty acids: A colorimetric method. Anal. Biochem. 1980, 107, 193-198. [CrossRef]

64. Tamaoku, K.; Ueno, K.; Akiura, K.; Ohkura, Y. New water-soluble hydrogen donors for the enzymatic photometric determination of hydrogen peroxide. II. N-Ethyl-N-(2-hydroxy-3-sulfopropyl) aniline derivatives. Chem. Pharm. Bull. 1982, 30, 2492-2497. [CrossRef]

65. Guilbault, G.G.; Brignac, P., Jr.; Zimmer, M. Homovanillic acid as a fluorometric substrate for oxidative enzymes. Analytical applications of the peroxidase, glucose oxidase, and xanthine oxidase systems. Anal. Chem. 1968, 40, 190-196. [CrossRef] [PubMed]

66. Guilbault, G.G.; Brignac, P.J., Jr.; Juneau, M. New substrates for the fluorometric determination of oxidative enzymes. Anal. Chem. 1968, 40, 1256-1263. [CrossRef]

67. Zaitsu, K.; Ohkura, Y. New fluorogenic substrates for horseradish peroxidase: Rapid and sensitive assays for hydrogen peroxide and the peroxidase. Anal. Biochem. 1980, 109, 109-113. [CrossRef]

68. Meyer, J.; Karst, U. Enzyme-linked immunosorbent assays based on peroxidase labels and enzyme-amplified lanthanide luminescence detection. Analyst 2001, 126, 175-178. [CrossRef]

69. Zhou, M.; Diwu, Z.; Panchuk-Voloshina, N.; Haugland, R.P. A stable nonfluorescent derivative of resorufin for the fluorometric determination of trace hydrogen peroxide: Applications in detecting the activity of phagocyte NADPH oxidase and other oxidases. Anal. Biochem. 1997, 253, 162-168. [CrossRef]

70. Zhou, M.; Panchuk-Voloshina, N. A one-step fluorometric method for the continuous measurement of monoamine oxidase activity. Anal. Biochem. 1997, 253, 169-174. [CrossRef] 
71. Mohanty, J.G.; Jaffe, J.S.; Schulman, E.S.; Raible, D.G. A highly sensitive fluorescent micro-assay of $\mathrm{H}_{2} \mathrm{O}_{2}$ release from activated human leukocytes using a dihydroxyphenoxazine derivative. J. Immunol. Methods 1997, 202, 133-141. [CrossRef]

72. Amundson, D.M.; Zhou, M. Fluorometric method for the enzymatic determination of cholesterol. J. Biochem. Biophys. Methods 1999, 38, 43-52. [CrossRef]

73. Batchelor, R.H.; Zhou, M. A resorufin-based fluorescent assay for quantifying NADH. Anal. Biochem. 2002, 305, 118-119. [CrossRef] [PubMed]

74. Hojjati, M.R.; Jiang, X.C. Rapid, specific, and sensitive measurements of plasma sphingomyelin and phosphatidylcholine. J. Lipid Res. 2006, 47, 673-676. [CrossRef]

75. Ota, H.; Tamezane, H.; Sasano, Y.; Hokazono, E.; Yasuda, Y.; Sakasegawa, S.; Imamura, S.; Tamura, T.; Osawa, S. Enzymatic characterization of an amine oxidase from Arthrobacter sp. used to measure phosphatidylethanolamine. Biosci. Biotechnol. Biochem. 2008, 72, 2732-2738. [CrossRef]

76. Wieckowski, M.R.; Giorgi, C.; Lebiedzinska, M.; Duszynski, J.; Pinton, P. Isolation of mitochondria-associated membranes and mitochondria from animal tissues and cells. Nat. Protoc. 2009, 4, 1582-1590. [CrossRef]

77. Smith, P.K.; Krohn, R.I.; Hermanson, G.T.; Mallia, A.K.; Gartner, F.H.; Provenzano, M.D.; Fujimoto, E.K.; Goeke, N.M.; Olson, B.J.; Klenk, D.C. Measurement of protein using bicinchoninic acid. Anal. Biochem. 1985, 150, 76-85. [CrossRef]

78. Folch, J.; Lees, M.; Sloane Stanley, G.H. A simple method for the isolation and purification of total lipides from animal tissues. J. Biol. Chem. 1957, 226, 497-509.

79. Abe-Dohmae, S.; Suzuki, S.; Wada, Y.; Aburatani, H.; Vance, D.E.; Yokoyama, S. Characterization of apolipoprotein-mediated HDL generation induced by cAMP in a murine macrophage cell line. Biochemistry 2000, 39, 11092-11099. [CrossRef]

(C) 2020 by the authors. Licensee MDPI, Basel, Switzerland. This article is an open access article distributed under the terms and conditions of the Creative Commons Attribution (CC BY) license (http://creativecommons.org/licenses/by/4.0/). 